\title{
Ecological and Economic Importance of Mulching Within the Urban Areas of Large Cities of the Republic of Serbia
}

\author{
Popović Slobodan*, Grublješić Željko, Popović Vera and Filipović Vladimir \\ Department of management, Institute of Field and Vegetable Crops, Serbia
}

Received: October 10, 2017; Published: November 07, 2017

*Corresponding author: Popović Slobodan, Department of management, Institute of Field and Vegetable Crops, Fund of the Republic of Serbian, Oslobodioca No. 6, 79101 Prijedor, Bosnia and Herzegovina, JKP Gradsko Zelenilo Novi Sad, Sutjeska, , 21000 Novi Sad, Serbia, Institute for Medicinal Plants Research “Dr Josif Pančić”, 11000 Belgrade, Serbia

\begin{abstract}
This paper indicates the advantages of using mulching in conditions of real exploitation in difficult terrain within the city area in the Republic of Serbia. The work was written to include impacts on specific ecosystems within cities, which are generally very heavy: burdened by passing a large number of vehicles, pedestrians, a large number of different stepping, and the influence of salting in the winter provision of transport and the impact of drought in the summer. The authors point out that the mulching observation was done basically with the economic aspect. In addition, it can be noted that there are numerous benefits of mulching which are underutilized in the real exploitation so far. On the narrow spaces, which are generally long, a few hundred meters to several kilometers, that are actually dividing strip, green islands has been raised over the past decade. In these conditions the application of machinery is difficult, and the entire processing is handmade. One of the models of problem solving is the application of mulching that fully meets the ecological and economic principles of management of public lands. The implementation of such an approach would mean reducing allocations taxpayers, and the results do not harm the ecological principles, but on the contrary, it would have positive impact on the areas of green spaces within cities.
\end{abstract}

Keywords: Mulch; The Economic and ecological impact; Urban surfaces

\section{Introduction}

Local governments and cities of the Republic of Serbia must develop the ecological-economic approach especially as imminent actual convergence of the Republic of Serbia with the EU countries. In the context of real convergence with the EU, the Ministry of Agriculture and Environmental Protection of the Republic of Serbia in recent years has made a large number of laws and decrees ordering the application of the greening of large urban areas while preserving the already planted green areas of cities. In order to perform these tasks with great appreciation spending funds taxpayers, cities must implement positive solutions to addressing the issues of ecology and economy. In this paper the authors have tried to find some answers, with the main purpose to broad population enjoys the benefits of the application of mulching. Mulching land, especially in the cities has advantages over passive observation of deterioration of green areas of cities or maintaining those with considerable financial allocations.

\section{Material and Method}

To make this work the authors used the documents public company founded by the city of Novi Sad. It has been operating in the market of Novi Sad and wider since 24.11.1962. Last bringing into line organization is done on the basis of the Decision of the City of Novi Sad, which was published in the Official Journal of the City of Novi Sad number 29/2005 and 53/2008 [1,2]. The survey was conducted in a representative and prestigious company with decade's reputation and with more than 400 full-time employees. This company is the second largest in the Republic of Serbia for landscaping, maintenance of green areas and other activities related to agriculture and ecology. Specificity maintenance of green areas in cities, especially in narrow areas is exceptional. There must be met by numerous factors such as: the visual experience for residents and visitors to the city, it is extremely difficult to do all agronomic operations because of the narrow space, difficult work processing operations of green spaces, because it must be provided leeway traffic, and there are great citizens' trampling green spaces.

Multidisciplinary approach for proper functioning of specific green spaces in cities, and green islands that are raised in large cities boulevards essentially begins with recognition of specific space $[1,3]$. In such difficult raise conditions the green areas that need to have multiple effects on users must be taken of the methods that will be applied. Authors gave the results of research which included the period $2012-2014$ by applying the classical methods 
of planting, mulching, and application of green areas, especially those which were planted perennial shrubs and short ornamental trees. In the classical model of raising seedlings on green islands we see many impacts of degradation, such as stepping on the soil, the irreversible removal of fertile surface layer during washing streets, the accumulation of snow on the green island with a large amount of salt, etc. For these reasons, it must be accessible to a different approach to try to somehow reduce part or most of the negative impact on the green island boulevards and other urban spaces. In this paper, the authors tried to answer some questions related to the degradation of these urban areas, i.e. erosion and reduction primarily surface layer of green area [4], using mulching on such spaces.

The point of all of these activities should be protecting of the surface layer of newly built green islands cities, and to better respond the ecological, visual experience of city dwellers, on the other hand these activities reduce costs taxpayers local communities and cities. Ecological approach is one of the primary in achieving humane life in big cities, and in order to approach full capacity it must include the science of marketing [5,6], which will long-term accompany any activity and with striking acceptable image at wide population [7-10]. In addition respecting the marketing [11] which will primarily explain to the citizens the significance of introducing new environmentally acceptable models for the community, and observation of socio-economic conditions [12] in which citizens live big cities is necessary. The application of the new mulching model in difficult environmental conditions for plants, as well as by demanding conditions for raising and maintenance of plant species in the cities, builds on previous research that includes a minimum investment of taxpayers with satisfactory effects $[13,14]$.

\section{Results}

Authors of this paper showed the survey based on a standard approach with raising green islands in the urban areas and boulevards in the big cities of the Republic of Serbia, and at the same time showing the possible results of the introduction of models that includes mulching space between the planted plants. (Tables 1,2) the authors present their research classical model and the planting and maintenance of urban areas with the use of mulching.

Table 1: The conventional method of planting and maintenance after the first year of vegetation numerical values for green islands in the cities or partial lane roads shrubs to $2000 \mathrm{~m}$ in length, width $0.5 \mathrm{~m}$, respectively $1000 \mathrm{~m}^{2}$ in the big cities of the Republic of Serbia.

\begin{tabular}{|c|c|c|c|c|c|c|c|}
\hline Plant species up to 1.5m & A & B & C & D & E & F & G \\
\hline Hardwood & 962 & 19,71 & 4,45 & 80,16 & 0 & 716 & 1782,32 \\
\hline Evergreen species brush & 120 & 4,93 & 2,34 & 8,21 & 0 & 179 & 314,48 \\
\hline Total & 1.082 & 24,64 & 6,79 & 88,37 & 0 & 895 & $2.096,8$ \\
\hline
\end{tabular}

Table 2: The method of planting with the use of mulching and maintenance after the first year of vegetation is shown in green islands in the cities, or dispensing lane roads shrubs at $2000 \mathrm{~m}$ in length, width $0.5 \mathrm{~m}$, respectively $1000 \mathrm{~m}^{2}$ in the big cities of the Republic of Serbia.

\begin{tabular}{|c|c|c|c|c|c|c|c|}
\hline $\begin{array}{c}\text { Plant species } \\
\text { up to } 1.5 \mathrm{~m}\end{array}$ & $\begin{array}{c}\text { The value } \\
\text { of average } \\
\text { seedlings } \\
\text { planting in } \\
\text { euro' }\end{array}$ & $\begin{array}{l}\text { The required } \\
\text { amount of } \\
\text { topsoil } 40 \mathrm{~cm} / \\
\text { value in euro's }\end{array}$ & $\begin{array}{l}\text { Transportation } \\
4 \mathrm{~m} 3 \text { country } \\
\text { at a distance } \\
\text { up to } 12 \mathrm{~km} \text { by } \\
\text { truck to } 8 \text { tons } \\
\text { in euro's }\end{array}$ & $\begin{array}{l}\text { The cost of } \\
\text { land clearing, } \\
\text { weeding, } \\
\text { planning, } \\
\text { leveling, } \\
\text { digging by } \\
\text { hand and } \\
\text { others in euro's }\end{array}$ & $\begin{array}{l}\text { Works by } \\
\text { manipulating } \\
\text { the country } \\
\text { when planting } \\
\text { in euro's }\end{array}$ & $\begin{array}{l}\text { The cost of } \\
\text { planting in } \\
\text { euro's }\end{array}$ & $\begin{array}{l}\text { Total cost of } \\
\text { planting by } \\
\text { the norms } \\
\text { of a public } \\
\text { company until } \\
\text { it is collected } \\
\text { by the local } \\
\text { government in } \\
\text { euro's }\end{array}$ \\
\hline & A & B & $\mathrm{C}$ & $\mathrm{D}$ & $\mathrm{E}$ & $\mathrm{F}$ & G \\
\hline Hardwood & 1.347 & 39,43 & 8,89 & 802 & 52 & 931 & $3.180,32$ \\
\hline $\begin{array}{c}\text { Evergreen } \\
\text { species brush }\end{array}$ & 168 & 9,86 & 4,68 & 200 & 13 & 233 & 628,54 \\
\hline Total & 1.515 & 49,29 & 13,57 & 1.002 & 65 & 1.164 & $3.808,86$ \\
\hline
\end{tabular}

Explanation of Tables:

$A=$ The value of average seedlings with the proposed structure of 80:20 (240 pieces sawmills: 40 pieces of evergreen species) planting in favor of sawmills in euro's

$\mathrm{B}=$ the required amount of topsoil $40 \mathrm{~cm} /$ value in euro's

$\mathrm{C}=$ Transportation $4 \mathrm{~m} 3$ country at a distance up to $12 \mathrm{~km}$ by truck to 8 tons in euro's

$\mathrm{D}=$ the cost of land clearing, weeding, planning, leveling, digging by hand and others in euro's
$\mathrm{E}=$ Works by manipulating the country when planting in euro's

$\mathrm{F}=$ the cost of planting in euro's

$\mathrm{G}=$ Total cost of planting by the norms of a public company until it is collected by the local government in euro's

Source: Author's calculation Table 2.

Results authors which were obtained are given in the table view $3^{\text {rd }}$ (Table 3).

Explanation of Tables: 
$A=$ The value of average seedlings with the proposed structure of 80:20 (240 pieces sawmills: 40 pieces of evergreen species) planting in favor of sawmills in euro's.

$\mathrm{B}=$ The required amount of topsoil $40 \mathrm{~cm} /$ value in euro's.

$\mathrm{C}=$ Transportation $4 \mathrm{~m} 3$ country at a distance up to $12 \mathrm{~km}$ by truck to 8 tons in euro's.

Table 3: Economic comparison of the classic ways of planting and maintenance of green islands towns and models that apply mulch to maintain the city's specific surface area of $1000 \mathrm{~m}^{2}$ in the big cities of the Republic of Serbia.

\begin{tabular}{|c|c|c|c|c|c|c|c|}
\hline \multirow{2}{*}{ Plant species up to $1.5 \mathrm{~m}$} & \multicolumn{7}{|c|}{$\begin{array}{l}\text { Value of plant seedlings, certain costs and work on raising the green islands } \\
\text { in cities }\end{array}$} \\
\hline & A & B & C & $\mathbf{D}$ & $\mathbf{E}$ & $\mathbf{F}$ & G \\
\hline The total value of the classical model expressed in euro & 1.515 & 49,29 & 13,57 & 1.002 & 65 & 1.164 & $3.808,86$ \\
\hline The total value of the model that uses mulching expressed in euro & 1.082 & 24,64 & 6,79 & 88,37 & 0 & 895 & $2.096,80$ \\
\hline The value of savings in favor of another model expressed in euro & 433 & 24,65 & 6,78 & 913,63 & 65 & 269 & $1.712,06$ \\
\hline
\end{tabular}

In this paper recalculating the average value of planting and maintenance of greenery with the use of mulching in the Republic of Serbia, as, were performed at the mean rate of the National Bank of the Republic of Serbia as of 05/12/201, compared to EUR $1=$ 123.17 dinars.

\section{Discussions}

There is a constant need for innovation of existing models of raising green areas, with the main purpose to improve the heterogeneous conditions of people's lives in cities.

a. Using the mulching model to a better and environmentally sound manner with small investment, we achieve better results in growing the desired plant species after planting (up to 50\%).

b. Citizens much less trampling and destroying perennial vegetation planted on green urban islands which raises the visual experience of inhabitants, less investments in restoration of plantation while reducing expenditures land of the upper layer and up to $100 \%$ compared to the classic model of planting and maintenance of the mentioned area.

c. Applying mulching model the plants are better able to withstand the accumulation of snow mixed with a large amount of salt, reducing the need for replacement of topsoil every few years.

d. Both models represents the cost for local government and cities in Serbia, except that the mulching model is about 55\% cheaper for taxpayers cities, while achieve better ecological and psychological effects on citizens.

e. According to the classical model of greening green urban islands on boulevards and other narrow places per $\mathrm{m}^{2}$ costs taxpayers about $3 €$, while using the mulching per $\mathrm{m}^{2}$ costs about $2 €$, which represents a decrease of about $52 \%$.

f. In the cities there is a need for continuous landscaping all narrower and more difficult terrain, which requires additional expenses related to greening and maintenance, the needs are continuously growing and increasing, therefore there is a need for the use of new models which give better results. One such
$\mathrm{D}=$ The cost of land clearing, weeding, planning, leveling, digging by hand and others in euro's.

$\mathrm{E}=$ Works by manipulating the country when planting in euro's.

$\mathrm{F}=$ The cost of planting in euro's.

$\mathrm{G}=$ Total cost of planting by the norms of a public company until it is collected by the local government in euro's. model authors presented through the use of mulching models in areas of cities.

This paper was created at the beginning of 2015, after years of research and real use of mulching models during the planting and maintenance of plant species in difficult terrain in cities in the Republic of Serbia. The authors provided realistic representations of the advantages of this model, based on the real exploitation mulching models compared to the classic model of raising greenery in cities. Just some of the advantages of using this model are shown. Raising the greenery inside the cities is the cost for local government, but also the obligation to the citizens. In this context it is important to find the optimum balance between the desires for ecological approach greening difficult urban terrain, but also the economy of costs, and the authors tried to show the real benefits of mulching compared to standard greening, primarily on the boulevards of cities. The application of the mulching is ecological and economically justified, and from the standpoint of saving by using mulching, we save about $50 \%$ of funds per $\mathrm{m}^{2}$. The application of the mulching is possible on different grounds, as well as in different countries, and the whole model is based on ecological principles that have a positive impact on soil and ecosystems suffer major environmental impacts.

\section{References}

1. (2005) Official Journal of the City of Novi Sad [Službeni list Grada Novog Sada] number 29/05.

2. (2008) Official Journal of the City of Novi Sad [Službeni list Grada Novog Sada] number 53/08.

3. Chan RYK, Lau LBY (2004) The effectiveness of environmental claims among Chinese consumers: Influences of claim type, country disposition and ecocentric orientation. Journal of Marketing Management 20(3): 273-319.

4. Dinu V (2011) Corporate Social Responsibility-Opportunity for Reconciliation between Economical Interests and Social and Environmental Interests. Amfiteatru Economic 13(29): 6-7.

5. Dancea L, Mazare V, Nita L, Gaica I, Merce L (2013) What is Good Ecological Restoration? ProEnvironment 4: 285-288.

\section{Conclusions}


6. Fisher CE, Chin L, Klitzman R (2010) Defining Neuromarketing: Practices and Professional Challenges. Harv Rev Psychiatry 18(4): 230-237.

7. Boanca PI, Dumitras A, Laczi E (2014) Integrated System in Landscaping Design and Landscape Ecology: Simplicity or Complexity? ProEnvironment 7(17): 46-52.

8. Cowart O, Goldsmith E (2007) The influence of consumer desisionmaking styles on online apperel consumption by college students. International Journal of Consumer Studies 31(6): 639-647.

9. Davis JJ (1993) Strategies for environmental advertising. The Journal of Consumer Marketing 10(2): 19-36.

10. Hort D, Cantor M, Buta E, Husti A (2013) Control of Soil Erosion on Slopes by Using Dendrological pecies. ProEnvironment 6: 499-502.
11. Lee N, Broderick AJ, Chamberlain L (2007) What is neuromarketing? A discussion and agenda for future research. International Journal of Psychophysiology 63(2): 199-204.

12. Popović S, Eremić-Đođić J, Grublješić Ž, Mijić R, Novaković S (2014) Unconventional marketing in agricultural enterprises. International Conference Ecological Truth 7(3): 342-347.

13. Popović S (2014) Socio-ekonomski faktori ograničenja razvoja agrara. Univerzitet Privredna akademija u Novom Sadu, monografija 90-96.

14. Popović S, Tošković J, Grublješić Ž (2014) Environmental-Economic Model of Developing Composters in Parks, Protected Areas and City Limits in the Republic of Serbia. ProEnvironment 7(20): 213-217.

\begin{tabular}{ll} 
BIOMEDICAL & Assets of Publishing with us \\
- GESERCHES & Global archiving of articles \\
\hline Immediate, unrestricted online access & - Rigorous Peer Review Process \\
& - Authors Retain Copyrights
\end{tabular}

